\title{
Upsurges of Timelessness: The Becket Tale between History and Dramaturgy in Tennyson's Becket, Eliot's Murder in the Cathedral and Anouilh's Becket, or the Honour of God
}

\author{
Sahar Awadallah \\ Department of English Language \& Translation \\ College of Science and Humanities, Jubail \\ Imam AbdulRahman Bin Faisal University, Dammam, Saudi Arabia
}

\begin{abstract}
The primary concern of this study is to explore the dramatization of the story of Archbishop Thomas a Becket, in three different plays by three prominent playwrights. These plays are Tennyson's Becket, Eliot's Murder in the Cathedral, and Anouilh's Becket, or the Honour of God. The study examines the three plays in the light of their manipulation of the details of Thomas Becket's contest with Henry II. The shifting relationship between the two men raised fascinating questions that were considered useful materials for playwrights. From the narrow confines of historical conflict, each of the three writers presented a unique artwork of a different dramatic vision. Through shedding light on the tale of the murder of Thomas Becket, this study highlights the significance of his fatal conflict with King Henry II to each of the three dramatists. First, it investigates how Tennyson's primary purpose was to write a work of "documentary" authenticity. Then, this paper clarifies how Eliot's interpretation of the play is a religious symbolic one. It also explores how Anouilh's employed the Becket tale to present his perspective of the dilemma of twentieth-century man. Thus, the purpose of this paper is to demonstrate how the different interpretations of the story in the three plays are not only distinctive in themselves but are also, in varying degrees, relating the past to the present.
\end{abstract}

Keywords: Anouilh's Becket, Eliot's Murder in the Cathedral, Historical Thomas Becket, Twentieth-century man's dilemma

Cite as: Sriastuti, A. (2020). Upsurges of Timelessness: The Becket Tale between History and Dramaturgy in Tennyson's Becket, Eliot's Murder in the Cathedral and Anouilh's Becket, or the Honour of God. Arab World English Journal for Translation \& Literary Studies 4 (4) 84-96.

DOI: http://dx.doi.org/10.24093/awejtls/vol4no4.7 


\section{Introduction}

The story of Thomas Becket has this fascination by reason of its clear-cut theme of a firm friendship turning to bitter enmity and crowned by a heroic death. On a deeper level, also, it has a powerful appeal, when it is conceived as the resistance of spiritual leadership to secular domain, as the endeavour of a reforming monarch to overcome obsecurantist and fanatical opposition.

(Knowles, 1971, p. ix)

In the year 1170, in the Canterbury Cathedral, Archbishop Thomas a Becket was murdered by four of King Henry II's knights. Since then, Thomas Becket's conflict with King Henry II has been the subject of many fictionalized accounts. This story of the most famous quarrel in Medieval English history, of the seven-year power conflict between the two stubborn antagonists who were formerly close friends, has furnished the dramatic material of notable plays. Though more than 800 years have passed since the murder of Becket, many playwrights were inspired to write their plays after reading his history. It has this fascination because of its clear-cut theme of a firm friendship turning to bitter enmity and crowned by a heroic death.

It was an interest in the different approaches to portraying the history of Thomas Becket that led to the writing of this paper. Since the twelfth century until the present time, the story of Thomas Becket has fascinated many writers. Hence, this paper focuses on the different interpretations of the Becket story, in three plays written by prominent playwrights. Those plays are Becket (1879), by Alfred Lord Tennyson, Murder in the Cathedral (1935), by the English dramatist and critic T. S. Eliot, and Becket or the Honour of God (1959), by the French dramatist Jean Anouilh. This study demonstrates that although these three plays seem similar in that they deal with the same story, they are incredibly different. The main differences lie in the vision and philosophy depicted in each of them and the themes, characterizations, and techniques developed.

\section{Literature Review}

The history of the two strong-willed antagonists Thomas Becket and King Henry II has been dealt with by many biographers. Among Becket's biographies are David Knowles's Thomas Becket (Leaders of Religion) (1971), James Robertson's Materials for the History of Thomas Becket, Archbishop of Canterbury (2012), Thomas Becket : Warrior, Priest, Rebel, Victim: A 900Year-Old Story Retold (2012), Alfred Duggan's My Life for My Sheep (1957), Thomas Jones's The Becket Controversy (1970), and Richard Winston's Thomas Becket (1967).

Knowles (1971) maintains that the Becket story has a powerful appeal when it is conceived as the resistance of spiritual leadership to a secular domain, as the endeavor of a reforming monarch

Arab World English Journal for Translation \& Literary Studies 
to overcome obscurantist and fanatical opposition. The story, as Jones (1970) maintains, presents an essential aspect of :

the nature of power in society about the interaction between personal rivals,...Did Henry try to take advantage of the goodwill of his friend, or did Becket reject and attack the friend who had promoted him...to the second most powerful position in the land? (p.161-2)

Becket was a self-centered man. He was also a proud man, who had lived chastely (Robertson, 2012; Knowels, 1971), and had a contradictory character. He was "courteous, fascinating, liberal to the poor and immensely popular" (Hayter, 1966, p. 104). It was believed by historians and biographers that Becket was murdered because of his "typical expression of the familiar, extravagant, Angevin passion" (Cannon, 1997, p. 509). Therefore, the character of Thomas Becket has inspired more than one dramatist to depict their vision of his history in their plays. Through Becket, these writers, "Expressed, to themselves and to us, how the creative imagination personifies and forms images; and how it establishes communication with the reader" (Hayter, 1966, p. 104). Hence, the objective of this study is to explore how each of the three plays by Tennyson, Eliot, and Anouilh, deals with the Thomas Becket's history from a different viewpoint.

\section{A Historical Perspective}

When Henry II came to the English throne, he recognized his need for an excellent chancellor. So, when Archbishop Theobald of Canterbury, whom Henry trusted to a great extent, introduced Thomas Becket to the King as one of his best clergymen, Henry instantly appointed him as his Chancellor. And in 1155, Thomas became Henry II's first Chancellor. He was ambitious yet very energetic and intelligent. Describing Thomas Becket, Duggan (1957) maintains that he

was always standing outside himself, looking to see how a man in his position was expected to behave. His chastity and sobriety showed that he was not really devoted to a life of luxury; he thought the chancellor of the Great King of England should live splendidly and kept such a state as he considered fitting. (p. 129)

Becket's loyalty, tireless energy, and administrative skills were so apparent to the King that he entirely depended on him. In a few months, Henry II and his Chancellor Thomas Becket became close friends. Although Becket was fourteen years older than Henry, the two men "became constant companions. They hunted together, ate and drank together, and shared adventurous excitement at a frenetic pace" (Jones, 1970, p. 1). The bond of friendship between the two men was so strong that no one ever imagined it would break later.

In April 1161, Theobald, Archbishop of Canterbury, died. Henry promptly thought of Thomas Becket as a successor to Theobald. Commenting on the reasons for Henry's choice of Becket for the highly religious position, Alverez emphasizes that:

Arab World English Journal for Translation \& Literary Studies 
Even before Becket became Archbishop, the relationship between the Crown and the Church was not cordial, owing to the King's wish that the clergy and the Church should pay taxes to the Crown. Henry II thought that by naming his intimate friend archbishop, he would solve both problems. (P. 75)

Counting on Thomas's loyalty and devotion to his position as a chancellor, Henry believed that he would then have an archbishop sympathetic with the Crown's interests. Henry was not thinking of his personal interests only but of his people, too. He felt that by having his best friend and companion as the Primate of the country, he could build a more powerful England governed only by the King. Meanwhile, Becket knew his friend so well that he realized the purpose of appointing him as an archbishop. He was aware that Henry was thinking of making him serve the royal power and interests over the Church's independence. Therefore, when Henry informed Becket of his intention to make him hold that position, Becket protested that he could not take hold of two conflicting offices by serving two masters simultaneously, both God and the King. But as Henry had no doubts about the change of Becket's loyalty towards the Crown, he insisted on his decision. Thus, in 1161 at the age of forty-three, Thomas Becket became the Archbishop of England. However,

It was not easy for Becket to get used to the idea...he had lived in the household of a holy archbishop and he knew how seriously and devoutly Theobald has performed his duties. He knew what an archbishop should do. (Duggan, 1957, p. 170)

This new position was like a temptation for Becket to sell himself to his King and friend. But his loyalty was always where it should be.

Secular and ecclesiastical governments were two extremes at that time. So, to avoid the dilemma, once Becket became an archbishop, he relinquished his position as the King's Chancellor. As soon as Thomas held the Archbishopric, both his thinking and habits underwent a significant change. Once he became an archbishop, to everyone's surprise, he changed from a worldly man into one dedicated to the Church. So, he sold all his luxurious properties and gave his money away to the poor. He renounced his old life entirely and lived humbly. And soon, instead of helping the King, Thomas Becket became an obstacle to all his plans.

Becket's change of life, however, has been a subject of debate. Knowles (1971), for instance, maintains that some biographers accused Thomas Becket of "alleged lack of consistency" and that others described his change as a part of "a consistent endeavor to suit his actions to the demands of his office for the time being" (p. 53). Knowles adds that some also described Becket as "a skillful actor who could play to perfection any part; to-day the extroverted jovial, efficient administrator, to-morrow the ascetic archbishop" (Knowles, 1971, p. 54). Knowles then argues that Thomas's change was not "a transformation or a rebirth of character" (p. 54). Knowles's opinion is considerably deepened by Winston's (1967), who points out that, "we will not find [Thomas's] change of heart surprising. There was nothing hypocritical about it" (p. 128). The apparent change in the character of Becket after he became an archbishop is confusing to many. 
It seems that it was a part of Thomas's nature that if he had to do something, he had to perfect it, and being loyal to his job was a part of this nature. This dichotomy represents one of the main themes in both Tennyson's play Becket and Jean Anouilh's Becket or the Honour of God, though it is tackled differently in each of the two plays.

At that time, the King, was planning to take control of the ecclesiastical power of England. Therefore, defending the interests of the Church, meant opposing the King. So, because of Becket's stubbornness, the seeds of the historical conflict between him and the unbending King were planted, and neither of the two men was ready to yield. All Thomas's predictions of the expected conflict were coming true sooner than he expected. It was also too hard for him to lose and to fight an old friend. Winston (1967) maintains that Becket "seems to have passed through a psychological crisis- scarcely surprising in view of the profound change in his life and situation within fifteen months" (p. 147). Indeed, Becket was overwhelmed by a sense of pride that caused him to be so stubborn. He sacrificed six years of close friendship and loyalty to the King for what he believed to be "saving the Church's order." The result is that he was left alone fighting his previously closest friend and could not retreat. Meanwhile, Henry decided to take vengeance of Becket, who blunted his dignity. As the struggle grew to be severe and threatened Thomas's life, his Bishops advised him to leave the country. So, Thomas crossed the channel to France, asking for the Pope's protection. In France, for six years, he remained in exile. In 1170, in France, Henry and Thomas met in another attempt at reconciliation. The two antagonists made peace so, Thomas returned to England and restarted the conflict with the King. When he was threatened with death by some of the King's Knights he said, "You will get nowhere threatening me with death; I have come to risk my neck for just and truth" (Winston, 1967, p. 120). So, with hurt pride, Henry was overwhelmed with famed wrath, and he uttered his fatal words: "Not one will deliver me from this turbulent priest?" (Duggan, 1957, p. 316) Four knights who heard the King's words took his threats seriously and interpreted them as an order to murder Becket. When they threatened to kill him, he said:

I commit myself and my cause to the Judge of all men. Your swords are less ready to strike than is my spirit for martyrdom. Find someone else to fly from you. Me you will find foot against foot in the lord's fight. (Knowles, 1971, p. 142)

When the knights began to stab him, Thomas showed no fear, "neither cry nor groan, nor any sound indicative of pain" (Jones, 1970, p. 55). Becket's reaction to his death adds more mystery to his character, as did not resist his murderers, and committed his cause to God. This ambiguity of Thomas's reaction at his murder was one of the dramatic elements that made his story an appealing subject to many writers. One of those writers is T. S. Eliot, who regarded Thomas Becket's death as a symbol of true martyrdom and built his play Murder in the Cathedral on the basis that he is a faithful Christian martyr and a saint.

The history of Thomas Becket raises critical issues that have been a source of inspiration for many dramatists. The theatrical events that marked that historical conflict are partly due to the rich personalities of Thomas Becket and Henry II. According to Hayter (1966), Becket "was a vain ambitious unloving man with no real friends, only admirers. He was prudent, astute, attentive: he 
was stern, combative and intransigent. He was energetic, chaste and sufficiently devout; he was truthful, ... a hardworking, and very efficient administrator" (p. 104). This contradiction in character has attracted more than one playwright to portray their vision of his personality in their plays. Furthermore, Henry's reaction towards Thomas's stubbornness was another appealing subject to dramatists. A man, a mighty king who could never control his wrath, whether in public or in private, his patience with Becket, his previous friend, for more than seven years was unexpected. It seems that, though disappointed by what he regarded as the ingratitude of Becket, Henry never lost hope in retaining his old friend. The nature of the previously exceptional relationship between the two antagonists and Henry's constant noble feelings towards Becket fascinated writers like Jean Anouilh. His play Becket, or the Honour of God, assumes that Henry can never hate Becket, even after he openly defies him and hurts his pride.

During the nineteenth and twentieth centuries, Becket's history was the topic of more than one play. In less than seventy years, three of these plays were published by three prominent writers, namely Tennyson (1879), Eliot (1935), and the French dramatist, Anouilh (1959). Although each of these three plays is directly dealing with Becket's history, each of them presents a unique and different vision of this history.

\section{Tennyson's Becket}

The only popular Becket story adaptation in the nineteenth century was Alfred Tennyson's Becket (1879). The play gained its popularity after Henry Irving, the popular nineteenth-century actor, produced it for the stage. The popularity of this play might also be due to the prominence of Tennyson himself as a Poet Laureate. Hallam Tennyson, son of Alfred Tennyson, maintains that his father intended to write the play, Becket, as a part of a "trilogy of plays which portrays the making of England". He adds that "In Becket, the struggle is between the Crown and the Church for predominance, a struggle which continued for many centuries" (2010, p. 173). Hallam, then argues that his father wrote this trilogy "to complete the line of Shakespeare's English chronicle plays, which end with the commencement of the Reformation" (2010, p. 173).

Tennyson had Becket printed in 1879, but got it published in December 1884 . He wanted very much to have his play produced for the stage. So, in 1893, the play was presented to the public and was a great success. In writing Becket, Tennyson took a great deal of trouble to keep close to the facts. Therefore, in August 1877, Tennyson visited the Canterbury Cathedral to see the actual setting of the murder. He also read Becket's letters, and the letters and writings of Herbert of Bosham, Fitzstephen, and John of Salisbury. Tennyson's close attention to the different original places and historical details of the Becket story with King Henry II reveals his desire to write a work of "documentary" authenticity. Seed (1982) maintains that Tennyson's

notion of history was potentially more sophisticated than Eliot's in that he wanted to do justice to the different issues which were simultaneously surfacing in the conflict between Becket and Henry. In other words, his notion of history was external, outside the text. Accordingly, he wanted to give expression to as many facts as he could. (p. 44)

Arab World English Journal for Translation \& Literary Studies 
Tennyson's primary purpose in the play was to depict the authentic attitudes of his main characters. Nevertheless, all along the unfolding of the play, he fails to present the reader with a coherent treatment of his characters. There are indeed moments when Tennyson succeeds in depicting Becket's internal feelings, especially when he sacrifices his friendship with Henry for the honor of the Church. But these moments are lost in the diversity of characters and incidents in the play. The too many details, of quarrels or victories that Tennyson depicts in the play overburden it. He is trying too hard to work these details that he even records, in a footnote, the thunderstorm that was said to break Canterbury when Becket was murdered. In other words, "unknowingly," Terry Otten argues that

Tennyson created his own dilemma.... Becket is clouded by the use of broad stage effects, and multifarious plotting. What might have been a study of character in the modern sense is instead more a comprehensive historical study modeled on nineteenth-century versions of Elizabethan drama. (1972, p. 92)

Tennyson's Becket needed more concentration on both characterization and plot structure than on "documentary" authenticity.

The central idea of Tennyson's play is the struggle of divided loyalties between State and Church. This conflict is depicted in the rising dispute between the strong-headed King and his stubborn Archbishop, Thomas Becket. The play develops two artificially interrelated plots. The main plot deals with the intimate friendship between King Henry II and his Chancellor Thomas Becket, which turns into hatred later. It portrays Henry's insistence on raising Becket into the Archbishopric, aiming at gaining control over the Church's affairs. Thus, Henry can put an end to his fears from the Church's growing independence, which might threaten his power as the King of England. After becoming an archbishop, to the King's disappointment, Thomas opposes him and persists in serving the Church's interests only. Thomas says, "I served our Theobald well when I was with him;/ I served King Henry well as Chancellor;/ I am his no more, and I must serve the Church" (Tennyson, 1982, p. 653). As the conflict grows steadily, Becket runs away to France, where he spends seven years in exile. When he returns to England, the dispute starts back again. Out of anger and despair of retaining his stubborn friend, Henry utters his famous words, "Will no man free me from this pestilent priest?" (Tennyson, 1982, p. 689) Full of hatred towards Becket, four of the King's knights, who hear the King's angry words, seek to see Becket at Canterbury Cathedral, where they murder him.

To this main plot, Tennyson adds another story, which starts very early in the play. This plot depicts a romantic story of protecting the life of fair Rosamunde de Clifford, Henry's mistress, from his wife, Queen Eleanor of Aquitaine. King Henry safely leaves the care and protection of Rosamunde to his friend Becket. When Eleanor attempts to kill her, Becket arrives and saves her. So, Eleanor and her henchman, Fitzurse, seek to take revenge on Becket. Later, when Fitzurse hears the King's angry words of his wish to get rid of Becket, he goes with the three other knights, to Becket and murders him. The connection between the two plots of the play is so mechanical and artificial, that it undermines the impact of the central theme of the play. Moreover, unfortunately, Tennyson's poetic gift, which appeared in many situations in Becket, was another weakness of the play. Tennyson creates beautiful images, which helped convey the feelings of 
anger, bitterness, and violence, throughout the unfolding of the play. For instance, Henry chooses Becket for the Archbishopric, hoping that Church and Crown would be "Two sisters gliding in an equal dance/ Two rivers gently flowing side by side" (Tennyson, 1982, p. 661). The beauty of these images, however, was lost because of the too many crowded events of the play. Moreover, in some situations, Tennyson's poetry was merely decorative, especially in the love scenes of Henry and Rosamunde.

In Becket, to portray the long-detailed struggle, Tennyson covers a long period of time. He ranges over Becket's whole career from the days of his earliest friendship with the King till his murder after the long conflict with the King. Tennyson also vividly portrays Henry and his court and works with historical figures as characters. His play is an accurate representation of the personages and events of the Becket- Henry conflict. Like Shakespeare, Ormond (1993) maintains that "Tennyson brings in lower-class characters, beggars and country people to comment on the designs of the great, directing our sympathy towards those who are unjustly abused by the court and the barons" (p. 182).

However, despite Tennyson's enthusiasm for Becket, it is "representative of his uncertain concept of the dramatic form" (Otten, 1972, p. 95). In Becket, Tennyson's concern about "documentary" authenticity causes him to fail to present a strong unifying theme of the play. For instance, he does not clarify the motives that drive Becket's conversion to his stubborn support of the Church; is it out of pride? Or is it out of his wish to be a martyr dying for a just cause? Tennyson fails to present the reader with a definite answer to these questions. All these elements add very much to the bulkiness and diffusion of the play.

\section{Where history halts}

This historical honesty, however, is not the same for Eliot's Murder in the Cathedral (1935) and Anouilh's Becket, or the Honour of God (1959). Though they deal with the same twentiethcentury story of Becket, the focus of these two plays is more about the problems of the twentiethcentury man rather than with Becket's accurate history. The modernist ideologies of the twentiethcentury man motivated modernist writers to reflect these changes in their works. Therefore, modernist works have sometimes become symbols of ideas and themes modernist writers wanted to illustrate. In 1935, Eliot wrote his play for the Canterbury Festival. In this play, he portrays his philosophical vision of Thomas as a martyr. And as Kohzadi and Azizmohammadi (2011) contend, the theme of Murder in the Cathedral demonstrates the "intersection of time and the timeless" (p. 2229).

Eliot has made clear that his motives in writing the play were "to concentrate on death and martyrdom." He added that he "wanted to bring home to the audience the contemporary relevance to the situation" (March \& Tambimuttu, 1965, p. 86). Unlike Tennyson, Eliot has dealt with the story from a religious perspective. His handling of the Becket tale is symbolic and unhistorical. Thomas Becket is portrayed as the symbol of a unique holy martyr who struggles with the subtle temptations of his religious conscience. Thus, the central point in the play, is not the murder of Becket but his martyrdom or, in other words, the meaning of martyrdom to a Christian. Becket, 
the uncompromising Archbishop, who becomes an enemy of the King, does not exist in the play. Instead, we see the character of Becket, as a symbol of the religious idea of Christian martyrdom, overwhelming the two parts of the play.

Though Eliot was very candid with history, he did not depend on the historical documentary at all. The play has a minimal action, addressing the emotions of a Christian audience. Eliot limited the story of the play to the last month of Becket's life. He compressed Becket's past life and the details of his conflict with Henry into incidental references by the other characters. Murder in the Cathedral's plot structure is very tight. It develops smoothly and straightforwardly. The play is written in two parts, and a sermon, or an Interlude. The two Parts are written in verse, while the Sermon in prose. Part One portrays the psychological preparation of Thomas Becket to become a martyr by facing different temptations that he can resist. In Part Two, Eliot depicts the physical action, or in other words, the actual murder of Becket. In the Interlude, as David Jones states, Eliot gives "expression to the self-knowledge that Becket has gained in Part One and shows him to make perfect [his] will in readiness for the action in Part Two" (Johns, D., 1970, p. 60). In this sermon or Interlude, Eliot (1979) explains the central theme of the play, saying

Martyrdom is always the design of God...It is never the design of man; for the true martyr is he who has become the instrument of God, who has lost his will in the will of God, and who no longer desires anything for himself, not even the glory of being a martyr. (p. 53)

Thus, Eliot uses the Interlude to reinforce Thomas's success to resist the temptations confronting him.

Like a Greek tragedy, the Chorus, represented by the poor Women of Canterbury, opens Part One of the play. This Part portrays Becket's return from France after seven years' exile. The poor Women, who symbolize contemporary man, pity the return of Thomas Becket to England. With his return, "there is no safety in the Cathedral. Some presage of an act / Which our eyes are compelled to witness" (Eliot, 1979, p. 11). Then, we closely watch Thomas's torture of the mind during the four Tempters' visit. The first three tempters symbolize his past by offering him things that no longer tempt him. The first tempter offers worldly pleasures, the second temporal delights through power and prestige by providing to make Becket a "master of policy/ Whom all acknowledged" (Eliot, 1979, p. 27). Then the third tempter offers to provide him with power, as an early ally of the ambitious barons against the King. Becket could easily reject these worldly temptations, saying, "No! Shall I, who keep the keys/ Of heaven and hell .... Descend to desire a punier power? (Eliot, 1979, p. 31) The fourth tempter, who is a symbol of religious glory, offers martyrdom. This martyrdom will bring Thomas spiritual saintly power of unlimited possibility, purifying his soul of the impure motives symbolized by the first three temptations. He says, "Think, Thomas, think of glory after death .... Saint and martyr rule from the tomb" (Eliot, 1979, p. 40). Thomas recognizes the hidden truth of this fourth temptation, which seduces him with his desire for martyrdom. So, he rejects it. Thus, by overcoming the fourth temptation of Pride, Thomas's soul is purified, and he is ready for martyrdom. Part Two opens with an ominous choral passage. Then the four knights who are planning to kill Thomas appear. They describe the various 
political charges against him and then, in an intensely moving climax, murder Becket. The knights' colloquial language has a dramatic function of linking the Twelfth-century story to contemporary life. Justifying their crime, the knights claim that Thomas "used every means of provocation: from his conduct, step by step, there can be no inference except that he had determined upon death by martyrdom" (Eliot, 1979, p. 89). Eliot, thus, strengthens the theme of martyrdom through building a coherent structure for the play. As Sharma argues,

What happens in Part I is just a prelude to what is going to happen in Part II. The struggle in Part one is at the spiritual level: it is an inner struggle. The struggle in the second is at the physical level: it is an external struggle. Nevertheless, the two struggles are part and parcel of the same pattern. (1976, p. 123)

Like in his other religious plays, Eliot's Murder in the Cathedral presents both physical and spiritual struggle together in one pattern. The use of the women of Canterbury as the Chorus in this play is also symbolic. These women represent the audience's reaction to Thomas's experience. Using the Chorus enables Eliot to relate the struggle between the spiritual and worldly values to the twentieth-century common man. Besides, in Part Two, the audience is involved in the experience. It turns into a congregation when Becket's murderers directly address it, justifying their murder in modern language. Patently, in Murder in the Cathedral, Eliot proves that a playwright can easily avoid "documentary" narrativity and manipulate history to outfit his perspective. And by involving the audience in Becket's experience, Eliot enforces the universality of his unique vision of martyrdom.

\section{The Search for Honor}

Anouilh (1960) narrates how he started writing his play, Becket, or the Honour of God (1959). He bought a copy of Augustin Thierry's history book, The Conquest of England by the Normans, in which he found an account of Becket and Henry's conflict. Anouilh was so captivated by the situation that he read only about thirty pages of the book and decided to write a play. He was moved by

this drama of friendship between two men, between the King and his friend, his companion in pleasure and in work (and this is what had gripped me about the story), this friend whom he could not cease to love though he became his worst enemy the night he was named archbishop.

(Anouilh, 1995, p. 3)

Becket or the Honour of God, which was translated into English by Lucienne Hill (1961), has gained critical and financial success in English production and French. It is regarded by critics as a significant twentieth-century dramatic work, as it develops different profound moral concepts that concern contemporary man to a large extent. In his play Becket, or the Honour of God, Anouilh does not stick to "documentary" authenticity. The theme, action, and characterization of Anouilh's play significantly differ from the authentic details of Becket's history. In this play, through emphasizing the theme of friendship between Thomas Becket and King Henry II, Anouilh depicts his view of man's indifference towards life. This phenomenon started to exist with the 
increase of materialism in the modern world. Anouilh has no interest in the historical accuracy of the play. Though in history, Becket is of a good Norman origin, in the play, he is a Saxon, a member of a conquered race. Henry, the great strong King in history, is Becket's Norman King by the right of conquest, a childishly immature person who depends on Becket to teach him everything. So, Anouilh, just like Eliot, uses the story of Becket merely as a source for his play. Then, he creates a unique artwork according to his own perspective.

The technique and plot structure of Anouilh's play is also different from the other two plays. Becket, or the Honour of God, is divided into four acts and over twenty-five scenes, in which Anouilh moves freely regardless of time or place. The play resembles a film scenario, in which every scene is preceded by Anouilh's directions. Even the facial expressions of the characters are described by Anouilh, in every scene. The play covers three decades, and its events happen in several countries and include different types of people, like kings, barons, peasants, and religious men. Anouilh also borrowed flashbacks from cinema techniques. The action of the play unfolds smoothly in flashbacks, depicting the development of the relationship between the two men Thomas and Henry. Anouilh traces Thomas's development of character and sense of honor throughout his various roles, starting in 1158, with a brilliant role as Henry's companion and Chancellor. During that time, Thomas used to say the right words and to make the right gestures. Therefore, he could preserve a firm sense of honor. That sense of honor was deeply causing him an internal struggle. But it became stronger when Becket became the Archbishop, as he has become God's servant. He says, "I felt for the first time that I was entrusted with something... I was a man without honour. And suddenly I found it- one I never imagined would ever become mine- the honour of God" (Anouilh, 1995, p. 102). Here, the inevitable conflict between idealism and realism begins, and Becket maintains his search. He refuses to improvise his values and insists on noncompromising with the people around him. So, he is murdered, sacrificing his life to defend the honor of God.

In Becket, or the Honour of God, Anouilh was exploring a truth: the concept which he chose for his subtitle, Becket's own phrase about "the honour of God". He seems to have been teased and fascinated by the phrase, what did it mean for Becket? How did it relate to the contemporary concept of honour, to Becket's personal honour, or lack of it? (Hayter, 1966, p. 93-4)

For Anouilh's play the themes of nonconformity, purity, and refusal to compromise are essential. His protagonist seeks recognition of himself. He is a man who is incapable of love. Even his sense of honor that he holds tight has been a meaningless label. It is an odd sense of honor that Becket defines by the ideal value related to it. He believes that his sense of honor is, in truth, an ideal to serve, to live for, or even to die for. He says, "We must only do- absurdly- what we have been given to do- right to the end" (Anouilh, 1995, p. 101). When he is ready to die, he sacrifices his life, for he loves "the honor of God" and not God Himself. Becket's honor "is achieved in solitude and defined in and by the actions to which he attaches the name: his definition is neither acceptable neither understandable to Henry or to the world in which Henry has chosen to live" (Gatlin, 1965, p. 283). 
In Becket, or the Honour of God, Anouilh portrays the social aspect of the story, which deals with the dilemma in which the modernist man lived. The play shows the inevitably universal conflict between idealism and realism. Henry is willing to compromise to get his wishes fulfilled, while Thomas refuses to compromise. He keeps in search of the ideal honor till, he sacrifices his life for what he believes to be the honor of God. Harvey (1964) points out that the emphasis in Anouilh's play is placed not on the idealism presence, "but on the gradual revelation of this idealism to the hero. Conflict authors itself within each protagonist: having placed his values beyond himself, the hero is impelled at once towards life and towards the ideal" (P. 91). Becket struggles hard to always act with honesty, but he finds that honesty is impracticable in a world that he believes to be meaningless. He says to Henry, "How tenderly I would love you my prince in an ordered world" (Anouilh, 1995, p. 46). Becket finds that his struggle is futile, but the battle between his idealism of a hypocritical world drives him to seek an escape that goes along with his romantic self. In his play, Anouilh illustrates the theme that man is always alone in his universe, deserted, helpless, struggling to restore and confirm his original purity. Hence, Anouilh employs the Becket story to reflect his vision of the condition of modernist man, who feels lost in a materialistic world.

\section{Conclusion}

The historical conflict between Archbishop Thomas Becket and King Henry II is regarded by historians as the most famous in Medieval England. The unstable relationship between the two men raised humanistic, social, political, and religious questions that were considered valuable materials for playwrights. Therefore, this shifting relationship was used as the primary source for the writing of three important plays by three significant writers. Each of these three plays deals with the Becket tale from a different perspective. Tennyson's play Becket focuses on the "documentary authenticity" of the landmark event. His focus in the play was on what was happening rather than how the conflict was developing. Meanwhile, Eliot and Anouilh were not concerned about settling the responsibilities on either Henry II or Becket. On a universal level, the two dramatists have taken liberties with the historical details to present their vision and philosophy of the Becket story. This study explored how Eliot's handling of the Becket tale is symbolic and unhistorical. The play is a psychological, religious drama that depicts the internal dilemma of a man struggling for his spiritual peace. In Murder in the Cathedral, Eliot enforces his vision that religion has a larger role in people's life than it is assumed to be. Unlike Tennyson and Eliot, Anouilh put the Becket story in a worldly order. A significant difference between Anouilh and the two other writers is his approach towards Becket's history. To reinforce his perspective of the Becket story, he changed many of its historical details. Becket, or the Honour of God portrayed the social aspect of the conflict. In this play, Anouilh explores his view of the human existence, as they could be understood in the shifting relationship between the two rivals, Becket, and Henry.

This paper demonstrated how the difference in handling the same subject in the three plays is striking. It revealed how much a historical story could be rich with meanings and themes that inspire writers. Each of the three playwrights has differently manipulated the historical conflict,

Arab World English Journal for Translation \& Literary Studies 
to give the reader a better insight into their philosophy of life. Each of them could handle this historical story in his play, creating a unique drama that shows no direct history, but a piece of art.

\begin{abstract}
About the Author
Dr. Sahar AwadAllah is currently an Assistant Professor of English Language and Literature, Department of English Language \& Translation, College of Science and Humanities, at Jubail, Imam AbdulRahman Bin Faisal University, Dammam, Saudi Arabia. Dr. Sahar Specializes in English language and literature interdisciplinary studies. She has presented in numerous international conferences in Europe and the Middle East.

Orcid ID: https://orcid.org/0000-0001-5835-9284
\end{abstract}

\title{
References
}

Alverez, C. G. (1983-84). Becket, Being and its Transcendency. Estudos Anglo-Americanos (78), 74-80.

Anouilh, J. (October 2, 1960). Becket by Chance. The New York Times (1), 3.

Anouilh, J. (1995). Becket, or The Honour of God. London, Methuen and Co, Ltd.

Cannon, J., ed. (1997). The Oxford Companion to British History. Oxford: The Oxford Press.

Duggan, A. (1957). My Life for My Sheep. New York: Coward- McCann, Inc.

Eliot, T. S. (1979). Murder in the Cathedral. London: Faber and Faber.

Gatlin, J. C. Jr. (1965). Becket and Honor: A Trim Reckoning. Modern Drama. December: 8(3), 277-283.

Jones, D. E. (1970). The Plays of T. S. Eliot. Toronto: University of Toronto Press.

Jones, T. M. (1970). The Becket Controversy. New York: John Wiley \& Sons, Inc.

Hayter, A. (1966). Thomas a Becket and the Dramatists. Essays by Divers Hands: Being the Transactions of the Royal Society of Literature of the United Kingdom (34), 90-105.

Knowles, D. (1971). Thomas Becket (Leaders of Religion). Stanford: Stanford University Press.

Kohzadi, H., \& Azizmohammadi, F. (2011). A Study of T. S. Eliot's Murder in the Cathedral. Australian Journal of Basic and Applied Sciences, 5(12), 2227-2230.

March, R., \& Tambimuttu. (1965). T. S. Eliot: A Symposium. London: Routledge.

Ormond, L. (1993). History and Drama. New York: St. Martin's Press.

Otten, T. (1972). The Deserted Stage: The Search for Dramatic Form in Nineteenth-Century England. Athens: Ohio University Press.

Seed, D. (1982). Eliot's use of Tennyson in Murder in the Cathedral. Yeats Eliot Review, 7(1-2) 42-49.

Sharma, H. L. ed. (1976). T. S. Eliot: His Dramatic Theories. New Delhi: S. Chand \& Company Ltd.

Tennyson, A. L. (1982). Tennyson: Poems and Plays. London: Oxford University Press. Tennyson, H. (2010). Alfred Lord Tennyson: A Memoir by His Son. New York: Nabu Press.

Winston, R. (1967). Thomas Becket. New York: Alfred Knopf.

Arab World English Journal for Translation \& Literary Studies 